This item was submitted to Loughborough's Research Repository by the author.

Items in Figshare are protected by copyright, with all rights reserved, unless otherwise indicated.

\title{
Asymmetric adjustment between oil prices and exchange rates : empirical evidence from major oil producers and consumers
}

PLEASE CITE THE PUBLISHED VERSION

http://dx.doi.org/10.1016/j.intfin.2013.10.002

PUBLISHER

(C) Elsevier

VERSION

AM (Accepted Manuscript)

LICENCE

CC BY-NC-ND 4.0

\section{REPOSITORY RECORD}

Ahmad, A.H., and Ricardo Moran Hernandez. 2019. "Asymmetric Adjustment Between Oil Prices and Exchange Rates : Empirical Evidence from Major Oil Producers and Consumers". figshare.

https://hdl.handle.net/2134/14025. 
This item was submitted to Loughborough's Institutional Repository (https://dspace.lboro.ac.uk/) by the author and is made available under the following Creative Commons Licence conditions.

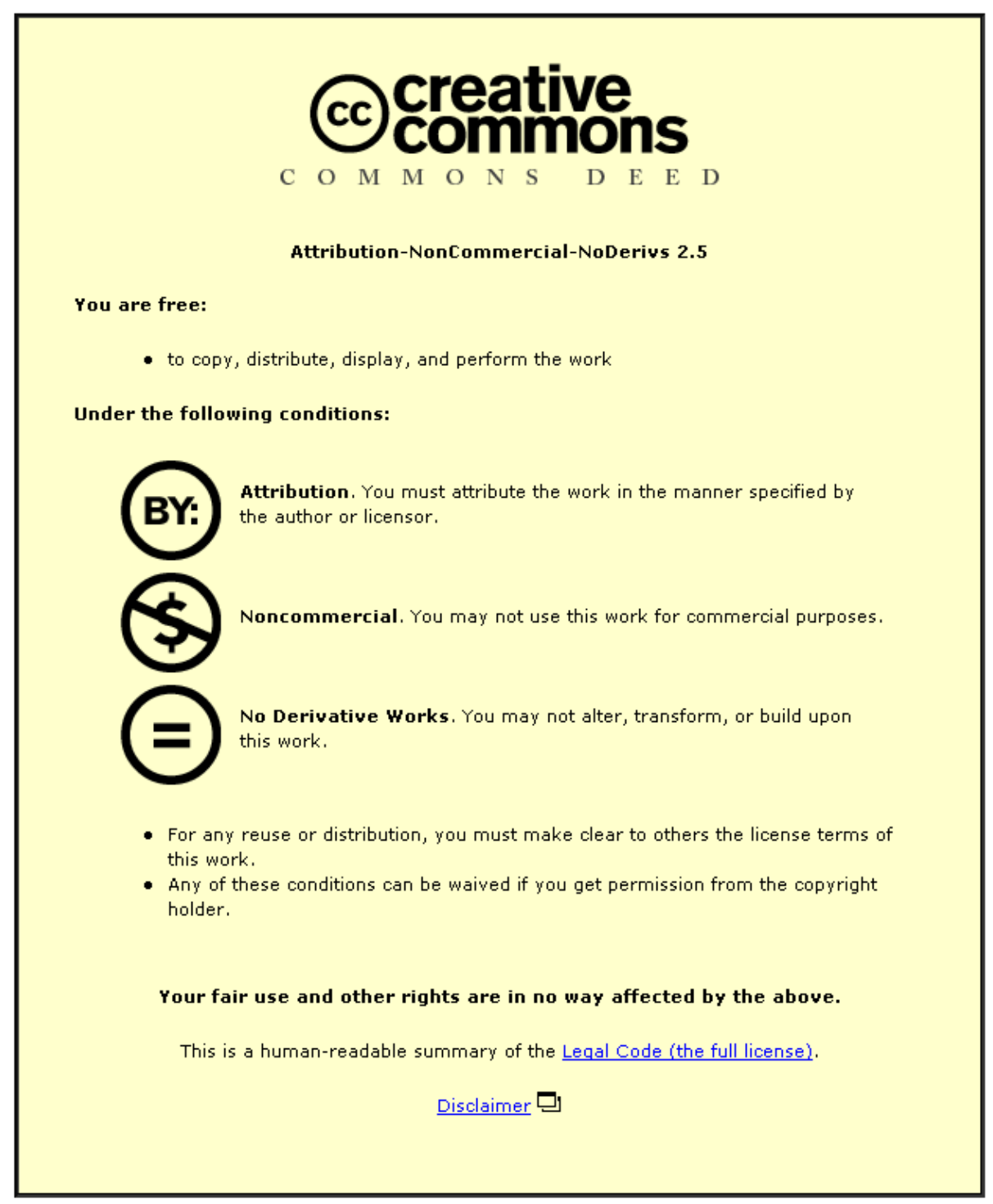

For the full text of this licence, please go to: http://creativecommons.org/licenses/by-nc-nd/2.5/ 


\title{
Asymmetric Adjustment between Oil Prices and Exchange Rates: Empirical Evidence from Major Oil Producers and Consumers ${ }^{1}$
}

\begin{abstract}
This paper investigates the long-run relationship and asymmetric adjustment between the real oil prices and the real bilateral exchange rates of twelve major oil producers and consumers in the world. It uses threshold autoregressive, TAR, and momentum threshold autoregressive, M-TAR models. The data-set used is monthly series that covers 1970:01-2012:01. The results reveal the existence of cointegration in six of the twelve countries studied and cointegration and asymmetric adjustment in four countries of which Brazil, Nigeria and the UK show higher adjustment after a positive shock than after a negative shock while the Eurozone shows the opposite behaviour.
\end{abstract}

Key Words: Exchange rates, Oil prices, Threshold cointegration, Asymmetry adjustments

JEL Classification: F30, F31, C22

${ }^{1}$ We are grateful for the useful and constructive comments we received from the anonymous referee. 


\section{Introduction}

Oil is one of the most important commodities traded in the world. Its many uses include a source of energy, a raw material in various industries and financial markets where many financial derivatives are based on it. Its price is primarily determined by market forces and hence variability of its price is very common. This will have an important effect on both the imports and exports of its major consumers and producers with a consequent impact on their exchange rates. This provokes interest in investigating the relationship between oil prices and exchange rates. Theoretical analysis of this relationship started with the work of Krugman (1980) where he showed that the initial effects of an increase in oil prices on real exchange rates differ from their long-run effects. In the former it is an appreciation and in the latter it is depreciation. Further work by Krugman (1983) proposes three models to explain the effects of oil shocks on exchange rates. The models suggest that oil shocks affect all countries, but their effects on the exchange rate depend on the asymmetries between the economies. Golub (1983) on the other hand, developed a stock/flow model that looked into the effects of oil shocks on exchange rates and concluded that the effects depend on the resultant direction countries take in reallocating their wealth. But the empirical literature is more dominant in this area.

Most of the literature in this area focuses on either single or several oil producing economies. The work of Corden (1984), Amano and Norden (1998) and Issa, Lafrance and Murray (2008) are on individual countries where as those of of Areta, Kamin and Vitanza (2011), Amano and Norden (1998) and Mundaca (2013) involve several oil producing countries. Corden (1984) studied the effects of discovery and subsequent 
production of oil in the North Sea on the rest of the Ducth economy in which the famous 'Dutch disease' was discovered. The Areta, et al. (2011) paper focuses on Mexico. Issa, Lafrance and Murray (2008) studied the relationship between energy prices and the Canadian Dollar. Amano and Norden (1998) investigated and found evidence of a long-run relationship between oil prices and the US Dollar exchange rates with respect to several major currencies. Mundaca (2013) analysed the effects of oil price shocks on the exchange rate volatility of Arab Monetary Fund countries with relatively high capital mobility. These papers have largely overlooked the effects that changes in oil prices could have in large developed economies that are dependent on oil imports or countries that are currently both large oil producers and consumers.

Further to the suggestions by the theoretical models that adjustment between these series could be asymmetric, it was also found that foreign exchange interventions as well as other monetary policies have been used by countries in order to influence the behaviour of their exchange rates ${ }^{2}$. This will generate asymmetries, which could be better modelled using non-linear techniques. However, most of the empirical literature uses linear models that include the Johansen cointegration and the Engle-Granger approach. Such linear models ignore the implications of monetary authorities' aversion to large changes in exchange rates as found by the sub-literature on exchange rate regime verification. Notable exceptions are Mohammadi and Jahan-Parvar (2010) who used threshold cointegration to investigate dynamics between the oil prices and exchange rates of Mexico, Norway and Bolivia, and Akram (2004) who studied the possibility of non-linear cointegration between oil prices and exchange rate for Norway.

\footnotetext{
${ }^{2}$ See Calvo and Reinhart (2002), Reinhert and Rogoff (2005) and Levy-Yeyati et al. (2005) among others for the empirical evidence.
} 
This paper extends this literature in the following ways. First, it investigates the relationship between exchange rates and oil prices in both large oil producers and consumers in the world. Unlike in the previous literature, this would allow us to analyse the effects of oil prices on exchange rates not only in small resource-based oil exporting economies, but also on large industrial economies where most of them depend on oil imports. Eleven countries and the Euro area, which consists of seventeen European countries, are chosen for this analysis. These countries are among the fifteen largest oil producers and consumers in the world. Secondly, unlike most of the literature in this area, the paper uses a non-linear methodology of cointegration based on threshold autoregressive (TAR) and momentum threshold autoregressive (M-TAR) models developed by Enders and Siklos (2001). Thirdly, using the estimated results, we explore the policy implication of the findings to these economies.

The paper finds evidence for the existence of cointegration in six of the countries covered while signs of asymmetric adjustments were detected in Brazil, the Eurozone contries, Nigeria and the UK. The results indicate that Brazil, Nigeria and the UK recorded higher adjustment after a positive shock than after a negative shock. Thus, real exchange rate appreciation following a rise in the real oil prices is eliminated faster than a depreciation following a fall in the real oil prices. However, the result for the Eurozone shows the opposite. That is adjustment is faster after a negative shock than after a positive shock. In addition, results for Brazil and the UK indicate Granger causality with respect to the real oil prices. 
The rest of the paper is structured as follows. Section 2 discusses the econometric model used in this study where the techniques of TAR and M-TAR are explained and Section 3 presents the data used and discusses the estimated results. Section 4 provides conclusions as well as examines some policy implications of the findings.

\section{Methodology}

Most of the countries covered in the study are on de jure floating exchange rate regimes. However, a de facto regime may differ with a de jure, which means the regime might not be floating, as monetary authorities often try to influence the behaviour of exchange rates ${ }^{3}$. Oil prices, on the other hand, are prone to large changes in very short periods of time. One example is the variations recorded in 2008. At the beginning of the year the price was 90.8 USD per barrel, but by July the price reached its historic peak of 132.5 USD per barrel and by December the same year the price fell to 41.5 USD per barrel, its lowest since December 2004. The standard deviation during the period of this study was 25.6 while the average price was 37.2 . This means that within a short period of time the income of oil exporting countries can vary in the same measure. These large fluctuations (of income of exporting countries) and their effects (on the expenditure of an oil importing country) from a single source can have a significant negative effect on the rest of their economies. As Corden (1984) observes, this may lead to asymmetric adjustments. This, therefore, makes threshold autoregressive, TAR and momentum threshold autoregressive, M-TAR models of Enders and Siklos (2001) appropriate for this study as they are better in picking up these asymmetries than the linear models of

\footnotetext{
${ }^{3}$ Calvo and Reinhert (2002) find that many countries that declared free floating regimes suffer from "fear of floating". This work and subsequent ones reveal that generally countries are less tolerant of exchange rate volatility and therefore, intervention aiming to stablise exchange rate is prevalent.
} 
Engle-Granger or Johansen cointegration models. The methodology involves carrying out two procedures where the first stage entails estimating a long-run relationship based on:

$$
y_{t}=\alpha+\beta x_{t}+\mu_{t}
$$

where $y_{t}$ and $x_{t}$ represent the logarithmic values of the two variables; real exchange rates and real oil prices and $\mu_{t}$ is an error term. The estimated residuals, $\widehat{\mu_{t}}$ are tested for stationarity. The second stage requires estimation of two parameters, $\rho_{1}$ and $\rho_{2}$ in the following equations:

$$
\Delta \mu_{t}=I_{t} \rho_{1} \mu_{t-1}+\left(1-I_{t}\right) \rho_{2} \mu_{t-1}+\varepsilon_{t}
$$

where $\mu_{t}$ is the residuals in equation (1) and $\varepsilon_{t}$, is a white noise disturbance. $I_{t}$ is the Heaviside indicator function, which takes the following values:

$$
I_{t}=\left\{\begin{array}{l}
1 \text { if } \mu_{t-1} \geq \tau \\
0 \text { if } \mu_{t-1}<\tau
\end{array}\right.
$$

where $\tau$ is the value of the threshold, which is unknown, but estimated endogenously. ${ }^{4}$ The threshold cointegration is determined by using the $\varphi$-Statistics proposed by Enders and Siklos (2001). Using the F-Statistic, the null of $\rho_{1}=\rho_{2}=0$ is tested against the alternative. The null hypothesis of no stationarity needs to be rejected in order to test for symmetric adjustments. Chan (1993) argues that in order to obtain a TAR model with a super consistent threshold, the sample needs to be estimated and the smallest $15 \%$ and the largest $15 \%$ of the values are trimmed off. The regression with the smallest residual

\footnotetext{
${ }^{4}$ See Enders and Siklos (2001) for details.
} 
sum of squares contains the appropriate threshold to use. This threshold is plugged into the $\tau$ value of the indicator function. For robustness checks, the residuals have to be checked for serial correlation. This was conducted using the Ljung-Box $Q$-statistic. Serial correlation can be removed by incorporating appropriate lags, which were determined by information criteria.

The momentum threshold autoregressive model is obtained by modifying the indicator function as follows:

$$
M_{t}=\left\{\begin{array}{l}
1 \text { if } \Delta \mu_{t-1} \geq \tau \\
0 \text { if } \Delta \mu_{t-1}<\tau
\end{array}\right.
$$

This is important, particularly, when the adjustment has more momentum in one direction than the other.

\section{Data and the Estimated Results}

\subsection{Data}

The data consists of monthly observations covering the period 1970:01 to 2012:01. These are the real oil prices and the real exchange rates of the domestic currencies of the countries considered with respect to the US dollar. ${ }^{5}$ There are many oil benchmarks in the oil industry which are used as reference, but the most common ones are West Texas Intermediate, WTI, North Sea Brent Blend, and Dubai Crude. West Texas Intermediate stands out from the three as it is used as a benchmark in the New York

\footnotetext{
5 The real exchange rate is constructed from the nominal exchange rate $e_{t}$, domestic currency per US Dollar, using $q_{t}=e_{t}+p_{t}{ }^{*}-p_{t}\left(\right.$ all in logs), where $p_{t}{ }^{*}$ and $p_{t}$ denote US CPI and domestic CPI.
} 
Mercantile Exchange to price other types of crude oil. This makes it the most appropriate one for this paper. However, in addition to WTI, an average of the three benchmarks is also used ${ }^{6}$. The two international oil price series; an average of the prices of West Texas Intermediate, WTI, Brent and Dubai crude prices and the West Texas Intermediate on its own are sourced from the United Nations Conference on Trade and Development (UNCTAD) database.

The currencies included are the Brazilian Real (BRL), the Canadian Dollar (CAD), the Euro (EUR), the Indian Rupee (INR), the Iranian Rial (IRR), the Japanese Yen (JPY), the South Korean Won (KRW), the Mexican Peso (MXN), the Nigerian Naira (NGN), the Norwegian Krone (NOK), the UK Pound (GBP) and the Venezuelan Bolivar Fuerte (VEF). The exchange rates are sourced from the World Bank Database, OECD, Eurostat and the European Central Bank. In the case of the Euro, its values from 1970 to 1979 are obtained from the European Unit of Account while those of 1979 to December 1998 are from the European Currency Unit. These constitute currencies from the fifteen largest oil producers and largest oil consumers in the world. However, other large oil exporting countries, such as Saudi Arabia, UAE and Iraq were not included in the study. This is because Saudi and UAE are on de facto fixed exchange rate regimes and Iraqi's economy has been undergoing upheavals since the 1990s, rendering its data, at best, suspicious for the full period ${ }^{7}$.

\footnotetext{
${ }^{6}$ The study uses real oil prices, which were computed by dividing the nominal prices by the ratio of the US Consumer Price Index (CPI) to the 2005 CPI. The base period, 2005 was used for the analysis.

${ }^{7}$ Russia, Libya, Kuwait and the US were not included in the study because Russia introduced CPI in 1992, which was considered too short for a long term study. Libya and Kuwait were also excluded due to lack of a reliable CPI. The United States Dollar (USD) was not included as series, but as the currency against which other currencies are measured.
} 
It is worth-noting that some of these countries are both among the largest oil producers and consumers (e.g. Mexico and Russia). For the European Union only the Euro and the United Kingdom Pound were included since Europe's large consumers (Germany, France and Spain) use the Euro as a currency, leaving only the UK as a large oil consumer with its own currency in the European Union. China is the largest oil consumer in the world after the US, but for most of the period studied its exchange rate was on de facto fixed regime. The Chinese central bank seems to adopt measures to keep the value of its currency, the Yuan less variable. It also lacks CPI series prior to 1978, thereby making it unsuitable for inclusion.

Table 1 reports the summary statistics for the data. The average price of the three benchmarks during the period is 24.90 US dollars per Barrel while the minimum is 0.47 US dollars in 1970 and the maximum is 143.34 US dollars per barrel in June 2008. The standard deviation for the period is 30.04 . The WTI has a mean of 25.75 US dollars per barrel, with a minimum of 0.63 US dollars during 1970 and a max of 160.59 US dollars per barrel in June 2008. The standard deviation is 30.19. Brazil, Korea and Mexico have their minimum values for their currencies at the beginning of the series, but their maximums are in 2002, 1997 and 2009, respectively. The maximum values for the Euro, the Norwegian Krone and the UK pound were recorded in 1995. Their minimum values, on the other hand, were recorded at different times. The UK pound had its lowest value in 1972, the Norwegian Krone in 1978, and the Euro in 2008. The Japanese Yen is the only currency with its maximum value at the beginning of the sample period and it's lowest at the end of the sample, January, 2012. India, Iran and 
Venezuela all have their lowest value during the 1970's decade and their maximum at the end of the period. The Canadian dollar's peak was in 2002 and its minimum was in 2007. This means that most of the currencies have depreciated against the US Dollar except the Euro, Yen and to some degree Canadian dollar. The Iranian Rial especially, has lost much of its value despite being one of the world's largest producers of oil. Its nominal exchange rate at the beginning of the sample was 75.9 IRR per USD. However, the currency depreciated to 10,589 IRR per USD by the beginning of 2012. In real terms the initial and final exchange rates are similar, but during the early 1990's it was almost three times the current real exchange rate.

\subsection{Unit Root Tests Results}

All the series were subjected to various unit root tests in order to determine their level of integration. The tests used are The Augmented Dickey-Fuller with General Least Squares (DF-GLS), Ng-Perron (NP) and Kwiatkowski-Phillips-Schmidt-Shin (KPSS). Although, the KPSS has a different null, it was used to complement the other unit root tests. Table 2 contains the results of the DF-GLS, Ng-Perron and KPSS unit root tests for each variable in levels and in first differences. All the variables fail to reject the null of a unit root at the 5\% level of significance. Conversely, all the series reject the null at $5 \%$ significance when tested for a unit root in first differences. The only exceptions are the Korean Won and Mexican Peso as both fail to reject the null at any conventional level of significance ${ }^{8}$. These countries however had important changes in their economic structures during the period considered so the results might have been affected by a structural break. Presence of structural breaks in series can lead to a false

\footnotetext{
${ }^{8}$ This is only for DF- GLS and Ng- Perron tests.
} 
rejection of the null of a unit root or otherwise. Lee-Strazicich Tests, which can test for a unit root with one or two structural breaks, were therefore used in order to address this. In addition, the tests can also identify the possible date(s) when the break(s) occur(s). The KPSS test also reveals a possible problem with the Norwegian Krone and the UK Pound so these two series were also tested by the use of the Lee-Strazicich Tests to see if they also have structural breaks. The results are reported in Table 3, which indicate that both the Won and Peso series fail to reject the null of a unit root with either one or two structural breaks. The identified dates are important for the respective countries; September 1997 and February, 1982. September 1997 was about two months after the beginning of the Asian financial crisis. Therefore, the results indicate that the crisis, which started in July 1997 in Thailand, took about two months to economically impact on South Korean. The 1980's decade was an especially difficult one for the Latin American economies. Many of them suffered from economic problems, particularly, foreign debt crises. For example, in August 1982 the Mexican government declared that it would not be able to pay its foreign debt. It followed a 90 days moratorium and it requested a renegotiation of its payment periods. The structural break in this case comes at an earlier date, which seems to reflect early anticipation by the markets. It could be concluded from the results, therefore, that both series have a unit root with structural breaks.

The UK Pound also fails to reject the null of a unit root with one structural break and rejects the null of a unit root with two structural breaks. The date given by the test was November 1982, which coincided with the Falklands war, fought between the UK and Argentina. Both the Pound and the Krone series became stationary when tested in first differences, so they are treated as $I(1)$. Results for the Norwegian Krone suggest 
presence of two structural breaks, which seems to be plausible. The first date given, February 1980 is very close to the period that the Norwegian oil industry experienced an accident that was considered the worst disaster in the North Sea since World War II and in its aftermath, a series of regulations regarding safety of operations were implemented in the oil industry. The second date, March, 2003, is not an event that affects the Norwegian economy alone, but it was the beginning of the latest oil crisis in the 2000 's that hit the world. It is clear from the results that all the series are integrated of order one, $I(1)$, which makes them suitable for cointegration analysis.

\subsection{Threshold Cointegration Results}

The tests for threshold cointegration were carried out using logs of the real exchange rates and the real oil prices for each of the countries in the sample as discussed in 3.1. The optimum lag length was determined by the use of the Schwarz Information Criterion (SIC) and the Ljung-Box Q-statistic was used to determine the model adequacy. Table 4 reports the results of cointegration tests with asymmetric adjustment using a TAR model and OIL denotes the average of the three oil benchmarks as explained above. The $\tau$ value is the optimal threshold for the indicator function. The results indicate that three currencies are cointegrated with the oil variable. These are the Korean Won, the Mexican Peso and the UK pound. In each case, the obtained values are higher than the critical value at a conventional significance level. However, none of the currencies shows signs of asymmetric adjustment. 
Table 5 presents results for threshold cointegration using WTI as a proxy for the oil price. The results are similar to the ones in Table 4 as both the Korean Won and the Mexican peso indicate signs of cointegration at conventional levels of significance $(10 \%$ and $5 \%)$ and no asymmetric adjustments were detected. However, unlike the results reported in Table 4, the UK Pound is not cointegrated with the real oil prices at the $10 \%$ level of significance. For the rest of the currencies the results are the same as in Table 4, but there is a general improvement over the ones that used OIL as the oil price, which is indicated by higher $\varphi$ - and F-statistics for most currencies 9 .

Table 6 reports the results for cointegration and asymmetric adjustment tests using an M-Tar model. The results indicate that the Korean Won did not show signs of cointegration at any conventional level of significance, but the Mexican peso did, just as in the previous results. Results for the Nigeria Naira and the UK pound indicate the presence of cointegration and both currencies show signs of asymmetric adjustments. The Nigerian Naira shows that adjustment after a positive shock is 27 times faster than a negative shock. Adjustment to equilibrium after a positive shock during the next period is about $20 \%$ while adjustment after a negative shock is only $0.7 \%$. Similarly, results for the Pound show that adjustment after a positive shock to the system is also faster than after a negative shock. The adjustment after a positive shock is $86 \%$, but only $3 \%$ after a negative shock, which is about 28 times higher.

\footnotetext{
${ }^{9}$ These results differ from the findings of Chang and Liu (2010). Although, they detected asymmetric adjustment, but their results indicate no existence of cointegration between the series for six oil exporting countries covered in their studies.
} 
Table 7 contains the results for cointegration with threshold using an M-TAR model and West Texas Intermediate. In general most of the results show an improvement over the ones using the OIL variable. The Brazilian Real, the Euro, the Mexican Peso, the Nigerian Naira and the UK Pound all fail to reject the null of cointegration at the $90 \%$ level of significance. Nigeria's Naira and the UK Pound have indicated signs of asymmetric adjustment like those reported in Table 6. In addition, the Brazilian Real and the Euro have shown signs of asymmetric adjustments as well. The Brazil's Real shows an adjustment of about $13 \%$ as a result of a positive shock, thirteen times higher than due to a negative shock, which is about $1 \%$. The Euro, on the other hand, is the only currency that shows a higher adjustment after a negative shock than after a positive one. It recorded $0.14 \%$ adjustment after a positive shock, but $3.5 \%$ after a negative shock. Nigeria's Naira has a higher adjustment after a positive shock than after a negative one; $19 \%$ of adjustment after a positive shock against only $0.7 \%$ after a negative one. The UK Pound shows a much higher adjustment after a positive shock with a value of $83 \%$ while the adjustment after a negative shock is just $3 \%$. Thus, the results for Nigeria's Naira and the UK Pound are similar to the ones reported in Table 6 using OIL variable.

\subsection{Granger Causality Tests Results}

Table 8 reports the results of the Granger Causality Tests for the exchange rates and the average oil prices, OIL. The results indicate that when OIL is used as the price series then the exchange rate of Brazil's Real Granger causes the oil prices. The UK Pound results show that OIL Granger causes the UK Pound exchange rate. The rest of the variables show no sign of Granger causality in either direction. Table 9 reports results 
for the Granger Causality Tests using the WTI oil variable. The results show that Brazil's Real exchange rate Granger causes WTI prices at the $95 \%$ level of significance.

Table 10 gives a summary of the Cointegration Tests both for the TAR and M-TAR models as well as Granger Causality Tests. Results using OIL and WTI as the price series are compared in this table. The TAR model reports cointegration for Korea's Won and the Mexican Peso, but no signs of asymmetric adjustment were detected for any of them. The UK Pound seems to be cointegrated with the OIL variable, but shows no signs of asymmetric adjustment. Result from the M-TAR based model shows signs of cointegration for the Mexican Peso, the Nigeria Naira and the UK Pound using the OIL variable. It also shows asymmetric adjustment for the Nigerian Naira and the UK Pound, but not for the Mexican Peso. The same model, but using WTI as the oil price series indicates the presence of cointegration for Brazil's Real, the Euro, the Mexican Peso, the Nigerian Naira and the UK Pound. All the currencies except the Mexican Peso show signs of asymmetric adjustment. As for Granger Causality Tests, only the UK Pound Granger causes oil prices when the OIL variable was used. However, when WTI is used as a proxy for the oil price, the Brazilian Real seems to Granger cause WTI. According to the results obtained from the TAR model, both the Korean Won and the Mexican Peso are cointegrated with oil prices, irrespective of the measure of oil used. But none of them shows signs of asymmetric adjustment. The results from the Granger Causality Tests show no causality in either direction was found. The facts that both currencies are cointegrated with oil prices means that oil prices not only have effects on small oil exporting countries, but also large developing countries depending on oil imports can be affected as well. Both Korea and Mexico had a large phase of industrialization during which the exchange rate was among the policy tools used 
during the period studied. Therefore, the exchange rate regime might have played a role in the adjustment process of the two series in these countries. Both currencies used a fixed exchange rate regime for most of the period covered with the Korean Won becoming fully floated only in 1997 and the Mexican Peso in 1994. This might have explained the fact that although cointegration was found, the result did not show signs of asymmetric adjustment.

The Brazilian Real was found to be cointegrated with WTI in the M-TAR model. It also shows asymmetric adjustment and the exchange rate Granger causes WTI. It is worthnoting that Brazil was the only country in the sample that went from being oil import dependent to an important oil producer during the sample period. This has an impact on the country's domestic oil demand and, the most important thing is that, there has been no manifestation of the "Dutch disease" or productivity bias. This might be due to the fact that it may take a relatively long period for the effects to be noticeable. However, the country only became self-sufficient in terms of its oil needs in 2006 . The results for the Euro are explained by the fact that many of the largest oil companies during the period covered were from the European countries, e.g. Royal Dutch Shell (UKNetherlands) and Total Group (France).

Results from the M-TAR model for the Nigerian Naira shows that the currency is cointegrated with both measures of oil price and it also exhibits asymmetric adjustments in both cases. This is not surprising as Nigeria is one of the largest oil producers in Africa, and has been an important oil exporting country for decades. Its oil industry is the most dominant in the economy. Similarly, the results from the M-TAR model, show 
the UK Pound is cointegrated with both measures of oil price and also shows signs of asymmetric adjustment in both cases. Although, currently, the UK is a net oil importer, but this period only covers a small part of the sample. Together with Norway, the Netherlands, Germany and Denmark, the UK runs oil operations in the North Sea as well. In Addition, two of the world largest oil companies are based in the UK (BP and Royal-Dutch Shell). This means that oil will have a significant impact on the economy, which further explains why the Pound Granger causes the OIL variable, the average of the three global oil benchmarks.

It is worth mentioning that Norway's Krone results are very close to rejecting the null of no cointegration, especially the results from the M-Tar model. The disturbances caused by the latest financial crisis appeared to have been reflected in the data. This is because when the sample size was shortened to July, $2007^{10}$, the results show that the currency is cointegrated with the WTI variable, but no asymmetric adjustment was found. ${ }^{11}$ The rest of the results remain the same as obtained from the full sample.

\section{Conclusion and Policy Implications}

This study looked into the existence of long run relationship with asymmetric adjustment between real oil prices and real exchange rates of twelve major world oil exporting and consuming countries, using the non-linear models; TAR and its variant M-TAR. The results show evidence of cointegration in six of these countries. These are Brazil, Eurozone, South Korea, Mexico, Nigeria and UK. Results from the M-TAR

\footnotetext{
${ }^{10}$ The structural break tests of Bai-Perron were used to determine this date.

${ }^{11}$ This is in contrast to Akram (2004) who did not find cointegration relationship between oil prices and the Norwegian real exchange.
} 
model for four of these countries (Brazil, the Eurozone, Nigeria and the UK) show signs of asymmetric adjustments. Two of them (Brazil and UK) also show signs of Granger causality with respect to oil prices. Brazil's real exchange rates seem to Granger causes oil prices while it is the opposite in the case of the UK pound.

According to the results, the longer a currency is under a floating exchange rate regime, the more likely it is to show signs of asymmetric adjustment. The Brazilian Real is an exception, but it was on a crawling peg regime before becoming fully floated. South Korean and Mexican currencies, on the other hand, were on a long transition between fixed and fully floating exchange rate regimes.

The relationship between oil prices and exchange rates has important policy implications, especially in countries that show significant asymmetric adjustment. Brazil, Nigeria and UK show much higher adjustment after a positive shock to the system than after a negative shock. This means that appreciation in real exchange rates following a rise in real oil prices is eliminated much faster than a depreciation following a decrease in oil prices. In other words, these countries are much more tolerant of a depreciation rather than an appreciation when driven by changes in oil prices.

The Eurozone shows the opposite behaviour. The adjustment is much faster after a negative shock to the system than after a positive shock. This means that, in this case, depreciation is eliminated much faster than appreciation. This is the opposite to the other three countries, the Eurozone seems to be much more tolerant towards 
appreciation than depreciation driven by oil price changes. Stricter control of South Korea's and Mexico's currencies seems to be responsible for eliminating asymmetric adjustments after changes in oil prices. The values of the adjustment coefficients differ, but they are not statistically significant. 


\section{Bibliography}

Akram, Q. Farooq, 2004. "Oil prices and exchange rates: Norwegian evidence", Econometrics Journal, 7, pp. 476 - 504.

Amano, Robert A. and Norden, Simon van, 1998, "Oil Prices and the Rise and Fall of the US Real Exchange rate", Journal of International Money and Finance, 17(2), pp. 299-316.

Arteta, Carlos, Kamin, Steven B. and Vitanza, Justin, 2011, "The puzzling peso", Journal of International Money and Finance, 30, pp. 1814 - 1835.

Benassy-Quere, Agnes, Mignon, Valerie and Penot, Alexis, 2007. "China and the relationship between the oil price and the dollar", Energy Policy, 35, pp. 5795 -5805 .

Calvo, Guillermo A. \& Carmen M. Reinhart, 2002. "Fear Of Floating," The Quarterly Journal of Economics, MIT Press, vol. 117(2), pp. 379-408,.

Chan, K. S., 1993, "Consistency and Limiting Distribution of the Least Squares Estimator of a Threshold Autoregressive Model," The Annals of Statistics, 21, 520-533.

Chan, T. and Liu, W., 2010. "Long-Run Purchasing Power Parity with Asymmetric Adjustment: Evidence from Nine Major Oil-Exporting Countries", International Journal of Finance \& Economics, 15, 263-274.

Clements, Kenneth, Lan, Yihui, and Roberts, John, 2008. "Exchange-rate economics for the resources sector", Resources Policy, 33pp. 102-117.

Corden, W. M., 1984. "Booming sector and Dutch Disease economics: Survey and consolidation", Oxford Economic Papers, 36, pp. 359 - 380.

Coudert, Virginie, Couharde, Cecile and Mignon, Valerie, 2011. "Does Euro or Dollar Pegging Impact the Real Exchange Rate? The Case of Oil and Commodity Currencies", The World Economy, 34 (9), pp. 1557 - 1592.

Enders, Walter and Siklos, Pierre L., 2001. "Cointegration and Threshold Adjustment", Journal of Business and Economic Statistics, 19 (2), pp. 166 - 176.

Engle, Robert F. and Granger, C. W. J., 1987. "Co-Integration and error correction: representation, estimation and testing”, Econometrica, 55 (2), pp. $251-276$.

Fardmanesh, Mohsen, 1991. "Dutch Disease Economics and the Oil Syndrome: An Empirical Study", World Development, 19 (6), pp. $711-717$.

Golub, Stephen S., 1983. "Oil Prices and Exchange Rates" The Economic Journal, Vol. 93, No. 371, pp. 576-593 
Issa, Ramzi, Lafrance, Robert and Murray, John, 2008."The turning black tide: energy prices and the Canadian dollar", Canadian Journal of Economics, 41 (3), pp. $737-759$.

Johansen, Soren, 1998. "Statistical Analysis of Cointegrating Vectors", Journal of Economic Dynamics and Control, 12, pp. $231-254$.

Krugman, Paul R. 1980. "Oil and the Dollar," NBER Working Papers 0554, National Bureau of Economic Research, Inc.

Krugman, Paul. 1983. "Oil Shocks and Exchange Rate Dynamics," NBER Chapters, in: Exchange Rates and International Macroeconomics, pages 259-284 National Bureau of Economic Research, Inc.

Lee, Junso and Strazicich, Mark C. 2003. "Minimum LM Unit Root Test with Two Structural Breaks", Review of Economics and Statistics, 85 (4) pp. 1082 1089.

Lee, Junso and Strazicich, Mark C., 2004. "Minimum LM Unit Root Test with One Structural Break", Appalachian State University Working Paper.

Levy-Yeyati, Eduardo \& Sturzenegger, Federico, 2005. "Classifying exchange rate regimes: Deeds vs. words," European Economic Review, Elsevier, vol. 49(6), pages 1603-1635, August

Mohammadi, Hassan and Jahan-Parvar, Mohammad R., 2012. "Oil prices and exchange rates in oil-exporting countries: evidence from TAR and M-TAR models", Journal of Economics and Finance, 36, pp. 766 - 779.

Mundaca, Gabriela, 2013. "Oil prices and exchange rate volatility in Arab countries", Applied Economics Letters, 20 (1), pp. 41-47.

Reinhart, Carmen M. \& Kenneth S. Rogoff, 2004. "The Modern History of Exchange Rate Arrangements: A Reinterpretation," The Quarterly Journal of Economics, MIT Press, vol. 119(1), pages 1-48, February. 


\begin{tabular}{lcrrr}
\hline \multicolumn{5}{c}{ Table 1 } \\
Descriptive Statistics & & \\
\hline Variable & Mean & Std. Dev & \multicolumn{1}{l}{ Min } & \multicolumn{1}{c}{ Max } \\
\hline Real (BRL) & 2.061408 & 0.6144 & 1.326382 & 4.492435 \\
Canadian Dollar (CAD) & 1.201763 & 0.152471 & 0.975476 & 1.600624 \\
Euro (EUR) & 3160.862 & 4231.009 & 0.495587 & 13010.57 \\
Rupee (INR) & 34.04772 & 11.07969 & 16.11907 & 51.6872 \\
Rial (IRR) & 6835.045 & 4798.166 & 690.5162 & 21375.73 \\
Yen (JPY) & 120.8006 & 33.12402 & 66.64429 & 228.3689 \\
Won (KRW) & 1053.513 & 145.7417 & 811.7742 & 1782.907 \\
Peso (MXN) & 12.58873 & 3.171686 & 8.802848 & 30.0445 \\
Naira (NGN) & 102.2463 & 53.68007 & 23.6058 & 258.2909 \\
Krone (NOK) & 6.877184 & 1.025471 & 5.255417 & 10.035 \\
Pound (GBP) & 0.662763 & 0.099731 & 0.475948 & 1.058907 \\
Bolivar (VEF) & 1.786607 & 0.750233 & 0.712307 & 4.55142 \\
Average (OIL) & 24.90144 & 30.04094 & 0.478364 & 143.3485 \\
WTI & 25.75737 & 30.19535 & 0.636277 & 160.5944 \\
\hline
\end{tabular}

\begin{tabular}{|c|c|c|c|c|c|c|}
\hline \multicolumn{7}{|c|}{$\begin{array}{c}\text { Table } 2 \\
\text { Unit Root Tests } \\
\end{array}$} \\
\hline Currencies & $\begin{array}{l}\text { DF-GLS } \\
\text { (levels) }\end{array}$ & $\begin{array}{l}\text { DF-GLS } \\
\text { (1st dif.) }\end{array}$ & $\begin{array}{l}\text { Ng-Perron } \\
\text { (levels) }\end{array}$ & $\begin{array}{l}\text { Ng-Perron } \\
\text { (1st dif.) }\end{array}$ & $\begin{array}{l}\text { KPSS } \\
\text { (levels) }\end{array}$ & $\begin{array}{l}\text { KPSS (1st } \\
\text { dif.) }\end{array}$ \\
\hline Real (BRL) & -2.003365 & -22.91882 & -8.64815 & -251.362 & 0.172479 & 0.091645 \\
\hline Canadian Dollar (CAD) & -1.483577 & -23.85779 & -5.25218 & -250.491 & 0.269419 & 0.172809 \\
\hline Euro (EUR) & -0.310479 & -9.1918 & -0.58694 & -108.777 & 0.705017 & 0.916103 \\
\hline Rupee (INR) & -0.68694 & -20.29269 & -1.73423 & -249.535 & 0.420192 & 0.312814 \\
\hline Iran (IRR) & -1.55855 & -19.86599 & -5.42009 & -247.896 & 0.32208 & 0.100585 \\
\hline Yen (JPY) & -0.925637 & -19.92827 & -1.94382 & -248.083 & 0.407215 & 0.259495 \\
\hline Won (KRW) & $-3.475184 *$ & -23.09793 & $-23.1162 *$ & -251.262 & 0.098237 & 0.029068 \\
\hline Peso (MXN) & $-3.296970 *$ & -27.96808 & $-21.2196^{*}$ & -239.463 & 0.267196 & 0.032858 \\
\hline Naira (NGN) & -2.483166 & -25.95415 & -12.6271 & -246.14 & 0.379187 & 0.134069 \\
\hline Krone (NOK) & -1.690091 & -22.26897 & -5.69047 & -251.491 & 0.117721 & 0.091269 \\
\hline Pound (GBP) & -2.396393 & -20.92097 & -11.5022 & -250.323 & 0.059851 & 0.048433 \\
\hline Bolivar Fuerte (VEF) & -1.900323 & -19.91356 & -7.89428 & -248.037 & 0.369959 & 0.114435 \\
\hline Oil prices (average) & -0.415775 & -8.294029 & -1.11807 & -94.716 & 0.501258 & 0.229681 \\
\hline West Texas Inter. & -1.796945 & -11.76623 & -8.18245 & -3783.41 & 0.503882 & 0.129348 \\
\hline $\begin{array}{l}\text { Critical Value } 5 \% \\
\text { *Indicates acceptance o }\end{array}$ & $\begin{array}{r}-2.89 \\
\text { ypothesis } a\end{array}$ & $\begin{array}{l}-1.941454 \\
\text { o but reject }\end{array}$ & at $1 \%$ & -8.1 & 0.146 & 0.463 \\
\hline
\end{tabular}

*Indicates acceptance of null hypothesis at $5 \%$ but rejection at $1 \%$

Values from MacKinnon (1996), Ng-Perron (200) Table 1 and Kwiatkowski-Phillips-Schmidt-Shin (1992 Table 1) 
Table 3

Lee -Strazicich Unit Root Test with Structural Break(s)

\begin{tabular}{lccc}
\hline & One structural Break & Two Structural Breaks & \\
\hline \hline Currencies & Test Statistic & Test Statistic & Break Date \\
\hline Won (KRW) & -3.4054 & -4.0239 & Sep-97 \\
Peso (MXN) & -3.7653 & -5.6457 & Feb-82 \\
Krone (NOK) & -2.898 & -3.294 & Feb-90 \& Mar-03 \\
Pound (GBP) & -3.6229 & -4.5571 & Nov-82 \\
Critical value 5\% & -4.239 & -3.61 & \\
\hline
\end{tabular}

Co-integration and Asymmetric Adjustment test. TAR Model (OIL) TAR Model

\begin{tabular}{lccccccc}
\hline Currencies & $\boldsymbol{\tau}$ & lags & $\boldsymbol{\rho}+$ & $\boldsymbol{\rho}-$ & $\boldsymbol{\rho}$ stat & F stat & Q stat \\
Real (BRL) & 0.11895 & 0 & $-0.01265(0.01071)$ & $-0.01718(0.01292)$ & 1.58141 & 0.0729 & 1.5774 \\
Canadian Dollar & & & & & & & \\
(CAD) & 0.01637 & 1 & $-0.00758(0.00956)$ & $-0.01230(0.01122)$ & 0.91154 & 0.1025 & 8.3924 \\
Euro (EUR) & 0.63669 & 3 & $-0.00275(0.00381)$ & $-0.00675(0.00434)$ & 1.46633 & 0.4796 & 21.9433 \\
Rupee (INR) & 0.07293 & 1 & $-0.00432(0.00597)$ & $-0.00383(0.00618)$ & 0.45429 & 0.0033 & 22.2527 \\
Iran (IRR) & -0.1231 & 0 & $-0.00356(0.00986)$ & $-0.01626(0.00880)$ & 1.77024 & 0.9215 & 4.7912 \\
Yen (JPY) & -0.0347 & 0 & $-0.01824(0.01083)$ & $-0.01315(0.00983)$ & 2.31181 & 0.1208 & 9.8544 \\
Won (KRW) & -0.0224 & 0 & $-0.04434(0.01460)$ & $-0.01418(0.01717)$ & 4.94991 & 1.7891 & 2.6393 \\
Peso (MXN) & -0.0774 & 0 & $-0.04611(0.01594)$ & $-0.04520(0.02451)$ & 5.88525 & 0.001 & 5.3123 \\
Naira (NGN) & 0.14032 & 0 & $-0.01955(0.01096)$ & $-0.00733(0.00875)$ & 1.94126 & 0.7585 & 5.6351 \\
Krone (NOK) & 0.02029 & 0 & $-0.02158(0.01280)$ & $-0.03400(0.01548)$ & 3.83061 & 0.3822 & 1.8677 \\
Pound (GBP) & 0.1065 & 1 & $-0.02796(0.01615)$ & $-0.04413(0.01648)$ & 5.04184 & 0.4946 & 1.383 \\
Bolivar Fuerte (VEF) & 0.02145 & 0 & $-0.01173(0.00970)$ & $-0.00989(0.01265)$ & 1.03672 & 0.0133 & 9.4716 \\
\hline
\end{tabular}

Co-integration and Asymmetric Adjustment test. TAR Model (WTI) TAR Model

\begin{tabular}{lccccccc}
\hline Currencies & $\boldsymbol{\tau}$ & lags & $\boldsymbol{\rho}+$ & $\boldsymbol{\rho}-$ & $\boldsymbol{\rho}$ stat & F stat & Q stat \\
Real (BRL) & 0.11451 & 0 & $-0.01296(0.01076)$ & $-0.01726(0.01300)$ & 1.6055 & 0.0649 & 1.5715 \\
Canadian Dollar & & & & & & & \\
(CAD) & 0.01626 & 0 & $-0.00832(0.00969)$ & $-0.01432(0.01124)$ & 1.18004 & 0.163 & 10.0728 \\
Euro (EUR) & -0.1883 & 1 & $-0.00351(0.00493)$ & $-0.00784(0.00555)$ & 1.24827 & 0.3398 & 2.1768 \\
Rupee (INR) & 0.0696 & 1 & $-0.00507(0.00643)$ & $-0.00447(0.00665)$ & 0.53599 & 0.0043 & 12.1641 \\
Iran (IRR) & -0.1415 & 0 & $-0.00372(0.00996)$ & $-0.01651(0.00889)$ & 1.79219 & 0.9155 & 4.4104 \\
Yen (JPY) & -0.0344 & 0 & $-0.01961(0.01113)$ & $-0.01396(0.01016)$ & 2.49411 & 0.1403 & 9.5396 \\
Won (KRW) & -0.0227 & 0 & $-0.04427(0.01460)$ & $-0.01428(0.01719)$ & 4.94185 & 1.7674 & 2.8113 \\
Peso (MXN) & -0.0773 & 0 & $-0.04668(0.01593)$ & $-0.04395(0.02453)$ & 5.89435 & 0.0087 & 5.28 \\
Naira (NGN) & 0.14129 & 0 & $-0.01996(0.01103)$ & $-0.00741(0.00884)$ & 1.98788 & 0.788 & 5.4263 \\
Krone (NOK) & 0.04178 & 0 & $-0.01983(0.01280)$ & $-0.03616(0.01532)$ & 3.98507 & 0.6685 & 1.8217 \\
Pound (GBP) & 0.10347 & 0 & $-0.02455(0.01628)$ & $-0.04344(0.01636)$ & 4.65915 & 0.6688 & 4.1145 \\
Bolivar Fuerte (VEF) & 0.01962 & 0 & $-0.01182(0.00972)$ & $-0.00962(0.01264)$ & 1.02923 & 0.019 & 9.2818 \\
\hline
\end{tabular}




\begin{tabular}{|c|c|c|c|c|c|c|c|}
\hline \multicolumn{8}{|c|}{$\begin{array}{c}\text { Table } 6 \\
\text { Co-integration and Asymmetric Adjustment Tests (M -TAR Model (OIL)) }\end{array}$} \\
\hline Currencies & $\tau$ & lags & $\rho+$ & $\rho-$ & $\varphi$ stat & F stat & Q stat \\
\hline Real (BRL) & 0.11895 & 1 & $-0.11057(0.04276)$ & $-0.01192(0.00839)$ & 4.30462 & 5.1479 & 1.0071 \\
\hline $\begin{array}{l}\text { Canadian Dollar } \\
(\mathrm{CAD})\end{array}$ & 0.01637 & 0 & $0.00510(0.01777)$ & $-0.01372(0.00795)$ & 1.53158 & 0.9358 & 10.5876 \\
\hline Euro (EUR) & 0.63669 & 3 & $-0.07411(0.03577)$ & $-0.00405(0.00287)$ & 3.14027 & 3.8111 & 21.8149 \\
\hline Rupee (INR) & 0.07293 & 3 & $-0.05953(0.04319)$ & $-0.00459(0.00426)$ & 1.52375 & 1.6039 & 10.5109 \\
\hline Iran (IRR) & -0.1231 & 1 & $-0.01098(0.00668)$ & $-0.02248(0.03796)$ & 1.51642 & 0.0891 & 2.7351 \\
\hline Yen (JPY) & -0.0347 & 1 & $-0.01327(0.00787)$ & $-0.03653(0.01952)$ & 3.18023 & 1.2182 & 5.156 \\
\hline Won (KRW) & -0.0224 & 0 & $-0.03621(0.01186)$ & $0.00182(0.03225)$ & 4.66356 & 1.2254 & 3.2611 \\
\hline Peso (MXN) & -0.0774 & 0 & $-0.04701(0.01414)$ & $-0.03614(0.04085)$ & 5.9171 & 0.0632 & 5.067 \\
\hline Naira (NGN) & 0.14032 & 0 & $-0.19775(0.04161)$ & $-0.00713(0.00680)$ & 11.8428 & 20.439 & 4.4533 \\
\hline Krone (NOK) & 0.02029 & 0 & $-0.05007(0.02188)$ & $-0.02065(0.01104)$ & 4.36716 & 1.44 & 2.2653 \\
\hline Pound (GBP) & 0.1065 & 0 & $-0.86505(0.19462)$ & $-0.03070(0.01131)$ & 13.5634 & 18.317 & 1.7794 \\
\hline Bolivar Fuerte (VEF) & 0.02145 & 0 & $0.01548(0.01703)$ & $-0.01782(0.00860)$ & 2.5593 & 3.046 & 7.8731 \\
\hline
\end{tabular}

\begin{tabular}{|c|c|c|c|c|c|c|c|}
\hline \multicolumn{8}{|c|}{$\begin{array}{c}\text { Table } 7 \\
\text { Co-integration and Asymmetric Adjustment Tests (M -TAR Model (WTI)) }\end{array}$} \\
\hline Currencies & $\tau$ & lags & $\rho+$ & $\rho-$ & $\varphi$ stat & F stat & Q stat \\
\hline Real (BRL) & 0.11451 & 1 & $-0.13846(0.04181)$ & $-0.01096(0.00841)$ & 6.27715 & 8.9795 & 1.1378 \\
\hline $\begin{array}{l}\text { Canadian Dollar } \\
\text { (CAD) }\end{array}$ & 0.01626 & 0 & $0.00410(0.01815)$ & $-0.01381(0.00802)$ & 1.5076 & 0.8152 & 10.3965 \\
\hline Euro (EUR) & -0.1883 & 1 & $-0.00140(0.00389)$ & $-0.03575(0.01085)$ & 5.50317 & 8.8131 & 1.7374 \\
\hline Rupee (INR) & 0.0696 & 3 & $-0.07062(0.03939)$ & $-0.00448(0.00465)$ & 2.06938 & 2.7815 & 11.0422 \\
\hline Iran (IRR) & -0.1415 & 0 & $-0.01071(0.00674)$ & $-0.01481(0.03772)$ & 1.33773 & 0.0114 & 4.9235 \\
\hline Yen (JPY) & -0.0344 & 1 & $-0.01481(0.00815)$ & $-0.03540(0.01944)$ & 3.3151 & 0.9522 & 3.3842 \\
\hline Won (KRW) & -0.0227 & 0 & $-0.03612(0.01185)$ & $0.00126(0.03241)$ & 4.63991 & 1.1731 & 3.4854 \\
\hline Peso (MXN) & -0.0773 & 0 & $-0.04701(0.01414)$ & $-0.03633(0.04085)$ & 5.92111 & 0.061 & 5.0584 \\
\hline Naira (NGN) & 0.14129 & 0 & $-0.19188(0.04134)$ & $-0.00736(0.00687)$ & 11.3438 & 19.382 & 4.8797 \\
\hline Krone (NOK) & 0.04178 & 0 & $-0.07364(0.03671)$ & $-0.02292(0.01018)$ & 4.54506 & 1.7724 & 2.162 \\
\hline Pound (GBP) & 0.10347 & 0 & $-0.83407(0.19203)$ & $-0.03114(0.01137)$ & 13.1796 & 17.421 & 1.8834 \\
\hline Bolivar Fuerte (VEF) & 0.01962 & 0 & $0.01529(0.01671)$ & $-0.01805(0.00865)$ & 2.59498 & 3.1379 & 7.5686 \\
\hline
\end{tabular}


Table 8

Granger Causality Tests (OIL)

\begin{tabular}{lrrr}
\hline Causality direction & \multicolumn{1}{c}{$F$-Stat } & \multicolumn{1}{c}{$p$} & lags \\
\hline $\mathrm{OIL} \rightarrow \mathrm{BRL}$ & 2.120597 & 0.14595752 & 1 \\
$\mathrm{BRL} \rightarrow \mathrm{OIL}$ & 4.41874 & 0.00161624 & 4 \\
$\mathrm{OIL} \rightarrow$ EUR & 0.84093 & 0.47188453 & 3 \\
$\mathrm{EUR} \rightarrow$ OIL & 0.08978 & 0.96564939 & 3 \\
$\mathrm{OIL} \rightarrow \mathrm{KRW}$ & 1.046969 & 0.30670092 & 1 \\
$\mathrm{KRW} \rightarrow$ OIL & 3.59404 & 0.01360769 & 3 \\
$\mathrm{OIL} \rightarrow \mathrm{MXN}$ & 0.01501 & 0.902539 & 1 \\
$\mathrm{MXN} \rightarrow$ OIL & 0.1255 & 0.94500397 & 3 \\
$\mathrm{OIL} \rightarrow$ NGN & 0.192076 & 0.66138393 & 1 \\
$\mathrm{NGN} \rightarrow$ OIL & 0.19696 & 0.89846105 & 3 \\
$\mathrm{OIL} \rightarrow$ GBP & 7.738672 & 0.00560927 & 1 \\
$\mathrm{GBP} \rightarrow$ OIL & 2.09921 & 0.09944276 & 3 \\
\hline
\end{tabular}

Table 9

Granger Causality Tests (WTI)

\begin{tabular}{lrrr}
\hline Causality direction & \multicolumn{1}{c}{$F$-Stat } & \multicolumn{1}{c}{$p$} & lags \\
\hline $\mathrm{WTI} \rightarrow$ BRL & 1.148041 & 0.28447651 & 1 \\
$\mathrm{BRL} \rightarrow$ WTI & 6.543206 & 0.01082226 & 1 \\
$\mathrm{WTI} \rightarrow$ EUR & 0.89086 & 0.44568204 & 3 \\
$\mathrm{EUR} \rightarrow$ WTI & 0.089183 & 0.76534198 & 1 \\
$\mathrm{WTI} \rightarrow$ KRW & 2.452801 & 0.11794803 & 1 \\
$\mathrm{KRW} \rightarrow$ WTI & 2.648249 & 0.104294 & 1 \\
$\mathrm{WTI} \rightarrow$ MXN & 0.00871 & 0.9256799 & 1 \\
$\mathrm{MXN} \rightarrow$ WTI & 0.004098 & 0.94898253 & 1 \\
$\mathrm{WTI} \rightarrow$ NGN & 0.446854 & 0.50414128 & 1 \\
$\mathrm{NGN} \rightarrow$ WTI & 0.807623 & 0.36925663 & 1 \\
$\mathrm{WTI} \rightarrow$ GBP & 3.094945 & 0.07914739 & 1 \\
$\mathrm{GBP} \rightarrow$ WTI & 0.809326 & 0.36875251 & 1 \\
\hline
\end{tabular}




\begin{tabular}{|c|c|c|c|c|c|c|c|c|c|c|}
\hline \multirow{3}{*}{$\begin{array}{l}\text { Currency } \\
\text { Price Variable }\end{array}$} & \multicolumn{8}{|c|}{$\begin{array}{c}\text { Table 10 } \\
\text { Summary of tests } \\
\text { Co-integrating Relations } \\
\end{array}$} & & \\
\hline & \multicolumn{2}{|c|}{$\begin{array}{c}\text { Under TAR } \\
\text { Model }\end{array}$} & \multicolumn{2}{|c|}{$\begin{array}{c}\text { Asymmetric } \\
\text { Adjustment }\end{array}$} & \multicolumn{2}{|c|}{$\begin{array}{c}\text { Under M- } \\
\text { TAR Model }\end{array}$} & \multicolumn{2}{|c|}{$\begin{array}{l}\text { Asymmetric } \\
\text { Adjustment }\end{array}$} & \multicolumn{2}{|c|}{ Granger Causality } \\
\hline & OIL & WTI & OIL & WTI & OIL & WTI & OIL & WTI & OIL & $\begin{array}{c}\text { WTI } \\
\text { Causes }\end{array}$ \\
\hline $\begin{array}{l}\text { Real (BRL) } \\
\text { Canadian Dollar } \\
(\mathrm{CAD})\end{array}$ & No & No & - & - & No & Yes & - & Yes & No & WTI \\
\hline Euro (EUR) & No & No & - & - & No & Yes & - & Yes & No & No \\
\hline Rupee (INR) & No & No & - & - & No & No & - & - & - & - \\
\hline Rial (IRR) & No & No & - & - & No & No & - & - & - & - \\
\hline Yen (JPY) & No & No & - & - & No & No & - & - & - & - \\
\hline Won (KRW) & Yes & Yes & No & No & No & No & - & - & No & No \\
\hline Peso (MXN) & Yes & Yes & No & No & Yes & Yes & No & No & No & No \\
\hline Naira (NGN) & No & No & - & - & Yes & Yes & Yes & Yes & No & No \\
\hline Krone (NOK) & No & No & - & - & No & No & - & - & - & - \\
\hline Pound (GBP) & Yes & No & No & - & Yes & Yes & Yes & Yes & Caused by Oil & No \\
\hline Bolivar (VEF) & No & No & - & - & No & No & - & - & - & - \\
\hline
\end{tabular}

